\title{
Article
}

\section{Engagement, estrangement or divorce? The new universities and their communities in the 1960s}

\author{
Vernon, Keith \\ Available at http://clok.uclan.ac.uk/18512/ \\ Vernon, Keith ORCID: 0000-0002-4673-1402 (2017) Engagement, \\ estrangement or divorce? The new universities and their communities in the \\ 1960s. Contemporary British History, 31 (4). pp. 501-523. ISSN 1361-9462
}

It is advisable to refer to the publisher's version if you intend to cite from the work. http://dx.doi.org/10.1080/13619462.2017.1305899

For more information about UCLan's research in this area go to http://www.uclan.ac.uk/researchgroups/ and search for < name of research Group>.

For information about Research generally at UCLan please go to http://www.uclan.ac.uk/research/

All outputs in CLoK are protected by Intellectual Property Rights law, including Copyright law. Copyright, IPR and Moral Rights for the works on this site are retained by the individual authors and/or other copyright owners. Terms and conditions for use of this material are defined in the policies page.

\section{CLoK}

Central Lancashire online Knowledge www.clok.uclan.ac.uk

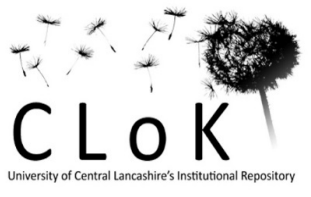




\title{
Engagement, Estrangement or Divorce?
}

The New Universities and their Communities in the 1960s

\author{
Keith Vernon \\ University of Central Lancashire
}

Preston

PR1 2HE

KVernon@uclan.ac.uk

01772893052

\begin{abstract}
The new universities of the 1960s were innovatory, in their curricula, architecture, independence, and academic ambitions. They also marked a different relationship between universities and their localities. For a century, new universities had been predicated on local demand, whereas the 1960s universities were conceived of as national institutions meeting a national demand. This new approach to university-civic connections was sudden, novel and contributed to a sense of remoteness attached to the new universities. This paper examines how the different policy was formulated, predominantly by the UGC, and considers some examples of how the policy played out in practice.
\end{abstract}

\section{Keywords}

Universities, communities, students 


\section{Introduction}

From the end of the 1950s, a decade of unprecedented academic innovation saw the formation of a whole set of new universities in England. ${ }^{1}$ Abandoning its customary caution, the University Grants Committee established seven entirely new institutions that were determinedly novel, in their campus form and ambitious architecture, aspirational curricular innovations and precocious academic autonomy. These universities were an important element in the post-war expansion of higher education in the UK, variously designated as the 'plateglass' or 'Shakespearian' universities, and part of a global phenomenon. Important aspects of their distinctive educational and architectural features have been studied, yet the focus has been rather insular, on the attempts to create innovative, experimental or even 'Utopian' academic communities. There is an implicit criticism carried by these terms; questioning the associations with historic cities and remote aspirations. The issue is compounded by the situation of the institutions on green fields, peripheral to their host towns. The historiographical emphasis echoes contemporary commentators who regarded the new campuses as detached, self-contained entities, physically and socially distant from their communities. ${ }^{2}$ Moreover, they readily accommodated themselves to very traditional university norms. Sussex was 'Balliol by the Sea', although perhaps with 'a bad conscience about its relations with the local community. ${ }^{3}$ It is not a uniform picture and there are important counter examples, but the prevailing view is of aloofness from the mundane world.

Such interpretations are somewhat at odds with broader perspectives on the development of English higher education in the twentieth century. There is a compelling narrative that, for the best part of a century, the establishment of new universities was dominated by a civic ideal. ${ }^{4}$ The universities of Manchester, Liverpool, Leeds, Birmingham, Bristol, Newcastle and Sheffield were born of local demand, initiative, commitment and not inconsiderable funding from industry and commerce, philanthropy, local authorities and communities. This mutual dependence was recognised in their appellation as 'civic universities' which was carried into the everyday life of the university. Scientific and technical departments developed specialisms relevant to local industrial strengths, English and History departments collected and studied local history and folklore, while nascent social scientists researched urban problems. Medical Schools were vitally important to the new civic universities and closely integrated with city hospitals and public health protection. Teacher training was a mainstay of the arts and science departments, which also drew on neighbouring schools to provide practical experience and universities served as the pinnacle 
of the educational system. Universities were centres of adult education, whether officially through agencies such as the WEA, or more informally through numerous public talks and lectures. Ultimately, the extent of local support was a key measure by which state authorities recognised higher education institutions as worthy of university status, and central state support was vital in enabling them to realise their civic function. ${ }^{5}$ Thus, the civic universities existed primarily to serve the cultural and academic, economic and professional needs and aspirations of their birthplaces; they were in, of and for the great Victorian cities in which they were founded. This ideal was maintained in shaping the emergence of the next wave of university colleges into fully-fledged universities through the middle decades of the twentieth century still named proudly after their home towns; Reading, Exeter, Hull and Leicester.

In the aftermath of the Second World War, there was an enormous expansion of higher education, with much greater central state direction and support. The emphasis was overwhelmingly on science, technology and professional expertise to meet the needs of economic development, military preparedness and the welfare state. ${ }^{6}$ In this respect also, the apparent separation of the new universities from worldly exigencies appears anomalous. A change in tone is exemplified in the names, apparent from the pioneering post-war institution. 'North Staffordshire' was chosen for an experimental university college, ostensibly because Stoke-on-Trent was the largest industrial conurbation lacking a university institution, but the campus was not built in or near the town. ${ }^{7}$ While the name might possibly be seen as accommodating the urban rivalries between the Potteries towns, ultimately naming it Keele felt like a snub to the locality. ${ }^{8}$ Its educational origins and isolated location gained it the unsympathetic soubriquet of the 'Balliol of the north.' In similar vein, the majority of the 1960s universities were not named after their home towns, thus the Shakespearian Sussex not Brighton, Warwick not Coventry.

In several respects, then, the 1960s universities, lacking civic identity or state-directed focus, seem out of kilter with the prevailing narrative. This article seeks to probe this anomalous sense of disengagement through an examination of the relationships between the new universities and their local communities. There are three main parts to the argument. We start with revisiting the policy formation at the University Grants Committee [UGC] that ushered in a wave of university formation at the end of the 1950s. While the general policy has been investigated before, here we focus specifically on how, in the course of those debates, the connections between university and locality were re-cast, undermining established traditions of civic engagement. In part, this was a result of higher educational 
developments elsewhere. It also derived from the growing mobility of students, who were less locally-based and becoming a national estate. The policy change was remarkably quick, although as quickly questioned and arguably very short-lived. It would be impossible here to make a comprehensive survey of how the new policy played out in practice but, to seek some understanding, two case studies are explored, Sussex as the first of the set, and the last, Lancaster. Nor can an extended period be considered, so the focus will be on the first few years of their existence, when relationships were being worked out and nascent institutions were most reliant on their hosts. The second part of the article discusses the more official connections between these institutions and their home towns, which struggled to find purchase. Finally, the relationships between students and their host communities are considered. Paradoxically, as the student body became more national, relationships with their neighbours became more intimate, with mixed consequences.

\section{Locating New Universities}

The formation of the 1960s universities came at the end of a remarkable period of higher education development after the Second World War. In a fervour of state-initiated national planning and reconstruction, the need for much greater scientific manpower was recognised; teacher training was expanded and re-organised; a range of specialist and professional education was reviewed; technical education was overhauled and the whole edifice underpinned by compulsory secondary education for all. ${ }^{13}$ Although existing universities grew significantly under these initiatives, much of the expansion was outside the established university sector with a number of new institutions elevated or enhanced. As such, most of the developments by-passed the University Grants Committee, whose role was confined to universities per se. Establishing new universities, though, was their responsibility, so it is crucial to analyse policy formation within the UGC. Their approach changed rapidly from a customarily cautious approach towards seizing the opportunity to implement some longgestating ideas. This section analyses the changing UGC ideas, specifically about the relationships between universities and their communities, which helped to shape the character of the new institutions. The focus is on the UGC, as this is where the key decisions were made, but other voices within the wider debate about higher education development soon questioned the UGC's approach. 
To appreciate the changes in UGC thinking, it is worth briefly reviewing its advent and role to the 1950s. From the mid-nineteenth century, university development in England had relied on prodigious levels of civic enterprise as the great industrial and commercial cities established university-level institutions, catering for local demand for higher education, professional training and technical expertise. ${ }^{14}$ State funding began in the late $1880 \mathrm{~s}$, in recognition and support of this effort. ${ }^{16}$ Grants increased fitfully under the recommendations of an ad hoc advisory committee, which emphasised local criteria. If a city wanted a university, it had to demonstrate serious commitment to the project and the levels of state grants were pegged explicitly to the amount of local support, in terms of cash, kind and student numbers. The civic universities were a means of bringing university-level education to centres of population that could not access the existing universities and the state, if a little reluctantly, was prepared to help to sustain this laudable goal. By the end of the First World War, it was clear that the universities could not survive without substantial state investment, so the UGC was created as a more formal body to distribute Treasury funds, and also to act as a buffer between the government and institutional autonomy. ${ }^{17}$ At the end of the Second World War, the UGC was assigned a more directive role, which it exercised cautiously, and according to well-established precedents. ${ }^{18}$ Three university colleges that had been developing from early in the twentieth century were elevated to full university status on the civic model. In a rare experiment, an entirely new college was created in north Staffordshire, ostensibly to provide for the Potteries region. ${ }^{19}$ By the mid-1950s, only one other place was under consideration. ${ }^{20}$ Brighton had been making a case from 1911 and could now muster sufficient local backing to make a further appeal. Having demonstrated long-standing commitment, and substantial local interest, the UGC was now prepared to countenance a new university college in Sussex. Within a few transformative years, the UGC had sanctioned the establishment of seven completely new and fully independent universities, with a very different kind of relationship to their hinterlands.

Spying a new venture in Brighton in the offing, other places broached the possibility of a university for their town but, at this point, the UGC response was cool. ${ }^{21}$ The UGC regarded new universities as uneconomical, even threatening, and admonished that it would take very substantial local support to attract their attention. Although it was envisaged that student numbers would rise, it was expected that existing institutions, plus Brighton, would be able to manage. Since more student places were anticipated, however, plans for a new building programme in the early 1960s would be required. The advent of Sussex was also still 
attracting attention, consequently, in the spring of 1959, the UGC established a subcommittee on new university institutions. ${ }^{22}$ To avoid attracting attention, or raise any hopes, this was to be an internal body with no necessity to publish a public report. No major change in policy was envisaged and a few non-UGC members were included primarily to 'dispel any misapprehensions that the Committee were so biased in favour of the existing institutions that they were not prepared seriously to consider new claims. ${ }^{23}$ When the sub-committee met for the first time, then, it saw its main task as simply putting a backlog of existing claimants into some kind of 'batting order' should the need for another university ever arise. ${ }^{24}$ This entailed defining a set of criteria in which long-established local factors were prominent. Local enthusiasm, both moral and practical, was crucial, as were the availability of appropriate cultural and recreational facilities to enhance the academic life of the university and to attract staff as well as students. The quality of schools became an increasingly important consideration, not as a feeder to the university, but to attract the families of suitably qualified academic staff. ${ }^{25}$

A fundamental shift in thinking came when a question was raised as to whether the notion of a catchment area was still relevant. ${ }^{26}$ From the late nineteenth century, catchment had been central to thinking about the location of universities. One of the key arguments in the establishment of the civic universities at the turn of the century was to cater for those unable to access university education elsewhere. ${ }^{27}$ In the early 1920 s, the pattern was clear, with $64 \%$ of students at the original civic universities living at home and $24 \%$ in lodgings. ${ }^{28}$ From the 1930s, however, more students were beginning to move away from their home towns. The trend was most apparent at the smaller university colleges in Exeter, Nottingham, Reading and Southampton, with smaller immediate population areas on which to draw and which actively sought to attract students from further away. In the early 1930s, then, at the older civics, $66 \%$ of students lived at home, $16 \%$ in lodgings and $18 \%$ in halls of residence. At the newer institutions, there were only $28 \%$ living at home, $13 \%$ in lodgings and $59 \%$ in halls. ${ }^{29}$ There were signs during the war that students were increasingly regarding the university system as a national one and after the war the pattern of student mobility became more pronounced..$^{30}$ By the early 1950s, for the older civics $44 \%$ still lived at home, but with $41 \%$ in lodgings and $15 \%$ in halls. Altogether, $53 \%$ of these students were identified as coming from within a 30 mile radius of the university. Meanwhile, the newly-elevated universities had $19 \%$ at home, $34 \%$ in lodgings and $46 \%$ in hall. Just $27 \%$ came from within 
30 miles. ${ }^{31}$ In its initial meetings, the sub-committee decided that catchment should no longer be a major consideration in the location of a new university. ${ }^{32}$

Itinerant students needed somewhere to live, which was an issue of much interest to the UGC. As the figures show, under the established civic model, most students lived at home. With greater mobility and independence, increasing numbers lived in lodgings. Neither inspired the UGC which, from the 1930s, had pressed for university-provided halls of residence, and re-emphasised the point in the post-war years as a central component of a university education. ${ }^{33}$ Halls of residence epitomised the academic community that the UGC wished to bring about, providing a complete experience of scholarship, society and culture. They were places where students of all backgrounds, interests and courses of study could come together in the formation of the whole person and were vital to the civilizing mission of the university. ${ }^{35}$ The emergence of a nationally mobile student estate and consequent demise of notions of catchment thus accorded with long-gestating ideas of model academic communities. Creating such a community, with appropriate facilities, accommodation and room to grow, clearly required a large site and this became another pivotal geographical point. The sub-committee debated whether a university should be central or peripheral to the town, with clear implications of how close the connections with local community life would be. The point was decided firmly in favour of out-of-town sites. ${ }^{37}$ A final twist in the debate, however, added a noticeably contradictory element. Halls of residence were the ideal, but notoriously expensive to provide so, paradoxically if pragmatically, alongside the vision of a campus community, a ready supply of lodgings in the locality also became a vital asset for a would-be university town.

When the UGC sub-committee first met, there was no real prospect for new universities, so some speculative thinking on ideal academic communities could be indulged. Very quickly the situation transformed as momentum gathered behind the creation of just such novel institutions. ${ }^{39}$ Thus, in the autumn of 1959, the sub-committee reconsidered the expressions of interest it had received and fourteen claims were categorised into three groups according to how far advanced the proposals were. ${ }^{40}$ An account of a visit by the subcommittee to York reflected, and contributed to, their thinking. ${ }^{41}$ In papers drawn up by the York promoters, they noted that the main factors determining the approval of a university in Brighton seemed to be a large local catchment area, strong financial support, the availability of a site and sufficient lodgings available during term time. It was argued that most of these were on offer in York but the catchment area argument was irrelevant. Although it had a 
good historical basis, it derived from an earlier age of poor communications and had something of a 'stagecoach flavour'. With its unique cultural amenities and attractions, and the increasing trend and educational desirability of students moving away from home, the York Academic Trust declared grandiloquently, '[t]he question of a local catchment area for students would not arise in the case of York: the catchment area would be the Englishspeaking world. ${ }^{42}$ Other voices also commented on the best locations for new universities. Various organisations of head teachers came out in favour of smaller towns with a more historical, ecclesiastical or scholarly tradition, such as York, Norwich or Gloucester. Even the Joint Advisory Committee on Engineering Education suggested that easy access to a centre of engineering activity was not essential. ${ }^{43}$ A memo from the Federation of British Industry went further, complaining that locating universities in large industrial centres perpetuated a cycle of local students from local schools attending their local university and going back into local employment. ${ }^{44}$ Instead, the FBI envisaged the engineering graduate as a 'full man' with cosmopolitan views, more likely to emerge from smaller institutions embedded in a diverse community with a liberalising influence.

At a formal meeting with the Treasury, the UGC presented its current thinking on new universities. ${ }^{45}$ A large local catchment area was now not seen as relevant and the advantages of a smaller town with room, fresh air and good communications could offset the cultural amenities of a big city. Significant local support, however, remained essential. Norwich and York were the front-runners and both places boasted good sites and promises of substantial local authority and industrial support, with great local enthusiasm. York had offers amounting to $£ 300,000$ plus a further $£ 100,000$ from Rowntree's which, it was noted, had the support of its workforce representing almost one household in three in the city. While local commitment remained a necessity, the UGC was decidedly reluctant to allow any local involvement in decision making. Suitable lay people were useful as representatives on symbolic governing bodies, so long as there were no sectional interests. ${ }^{46}$ Governance, however, must lie with a few good academic managers on the university Council. One of the key innovations in establishing the new universities was the Academic Planning Boards to advise on the initial creation of the institution. ${ }^{47}$ The chairman of the Norwich board demanded that local representatives should not be members of the committee as '[i]t tends to lower the sights'. ${ }^{48}$ Someone with local knowledge was invaluable to supply information, but they should not play an active role unless they also happened to be an eminent academic. 
Developments proceeded apace, with revised estimates of the demand for university places indicating that several more new institutions would be required. Following their meeting with the Treasury, the UGC issued a formal memorandum, publicly summarising the developments of the last year and setting out its new policy. ${ }^{49}$ It was now clear that demand was much greater than anticipated and that there was little prospect of much further growth at existing institutions. Thus, new universities would be required and the UGC needed to encourage their foundation.

We have said "encourage their establishment" for this reason. It has not hitherto been the practice in this country for the Government to establish new Universities or University Colleges. Most of these have been brought into existence as a result of local enthusiasm and enterprise, supported by local finance.'

Although the situation was different from that in the late nineteenth and early twentieth century

'[n]evertheless we assume that it would still be the view of the Government that, generally speaking, local interest and effort are essential preconditions to the establishment of a new institution and that it should be for those concerned in a given area, and not the Government, to take the effective steps to that end. ${ }^{50}$

There was no point in the UGC founding a university where it was not wanted, so evidence of local enthusiasm was a reasonable requirement. Material support from local government and commercial concerns, as well as a ready supply of lodgings, were also a necessity in bringing down, however marginally, the costs of very expensive ventures. Potential locations had also to possess at least some cultural resources. However, UGC thinking essentially conceived of new universities as national institutions drawing on a national clientele and designed to meet a national demand for university places. They had a vision of a model academic community and sought places where it could be brought into being. There was thus no necessary connection with the host community and where exactly these institutions would be located was entirely serendipitous, based on wherever offered to sustain one and had the resources to do so. There was no sense of local or regional needs, or overall social and economic planning and the role of the UGC was simply to determine which applications could best support its academic vision.

Some voices did question the wisdom of this policy, which gave the UGC pause for thought. A more considered regional approach had been broached in a short but influential article by W. G. V. Balchin, Dean of Science at University College, Swansea. ${ }^{51}$ On his analysis, the early twentieth century universities had been founded in the major centres of 
population and, of the next seven largest towns, five had since acquired one. If the same principle was applied to the formation of a new set of universities, a statistical calculation indicated 14 towns of about equivalent size with the resources to sustain one. Although a somewhat simplistic analysis, it offered a rationale for thinking about the location of universities on a broader national scale according to clear geographical criteria. Very effectively, his article included an accessible pictorial representation of the case for regional planning. A similar argument was made from a town planning perspective in an article by D. E. C. Eversley of the University of Birmingham, which reached the Chairman of the UGC, Keith Murray. ${ }^{52}$ Eversley pointed out the significant impact that universities could have on an area via the 'multiplier effect' on local employment and revenue, and that this should be taken into account for planning purposes. Murray asked for further details as Eversley's multiplier was much higher than that usually referred to by local authorities. Eversley forwarded the information and added 'I am very profoundly disturbed by the idea that your Committee feels that it has no say when it comes to any positive policy on location of universities. ${ }^{53}$ A crucial decision, he added, might depend on the serendipitous whim of an industrialist or philanthropist or the ill-conceived aspirations of a local authority. Murray replied, a little shame-faced, that town planning factors were taken into account, but this was for local authorities to sort out.

Questions about the proper location of new universities were also raised at an important forum convened under the auspices of the Universities Quarterly. ${ }^{54}$ Opening proceedings, Fulton, Vice-chancellor at Sussex, argued in favour of the campus ideal where students arrived from across the nation, where studying and residence were in one place, and a collegiate atmosphere could be created. The civic campaigner Armytage was sceptical, maintaining that universities should have greater engagement with their regions, embracing rather the exigencies of life in Grimsby and Scunthorpe than the cloisters of Norwich. The meeting's reporter noted that the debate was conducted in highly subjective terms with little real research or dispassionate reasoning about where universities ought properly to be sited. He asked whether it was really to be a free-for-all competition between local authorities with the UGC merely adjudicating between rival applications? The Ministry of Education was also more attuned to regional considerations, with its responsibilities for technical education and teacher training. ${ }^{55}$ They wanted to associate training colleges with university centres and endorsed Canterbury and Coventry as potential sites. Elsewhere, the Ministry identified gaps 
in southern East Anglia, while Chester had a large training college if a new place was sought for the northwest.

For now, the UGC maintained its approach, but regional considerations were coming more into play. Canterbury and Coventry were already being identified by the UGC as the next leading contenders, although Coventry posed problems because the existing Lanchester technical college worked to an advanced level and had claims to be of higher-educational status. ${ }^{56}$ Essex was also being strongly promoted, although the local authorities favoured Chelmsford while the UGC preferred more rarefied Colchester and worked surreptitiously to steer the proposal their way. ${ }^{57}$ With Norwich and York underway, and Warwick, Kent and Essex in the pipeline, there was a feeling that one more was required. Plymouth and Bournemouth were seriously considered, but Plymouth was too close to Exeter and its proposed site too far from the town. ${ }^{58}$ The Bournemouth promoters seemed more keen on having a university as an adornment to the town, than acquiring an academic institution. Some voices from within industry were now suggesting that any additional university should not be in an ethereal cathedral city, but should be more interactive with industry, research organisations and population. ${ }^{59}$ Carlisle was mentioned as a possibility and it was even suggested that the UGC could take the initiative in selecting an area. Surely, the conviction grew that the last institution should be based in the northwest and Lancaster emerged as the leading candidate. ${ }^{60}$ Lancashire County Council put together a serious application, leapfrogging other languorous contenders, but the change in priorities was made clearly in answer to a Parliamentary question. ${ }^{61}$ When asked why new universities were not placed near London, the response was that the south east was already congested with higher education facilities and any more would only encourage unwelcome population drift to that area. Since students tended to stay where they studied, it was worth locating a university where it would boost a region. 'This was one of the considerations which led the Committee to recommend Lancaster.'

As the new universities were getting underway, a different phase of government thinking was set in train with the Robbins committee, with regional considerations much more to the fore. ${ }^{62}$ For advice, the Treasury drew up a report on the location of further places of higher education, which highlighted the need to take regional economic factors into account. ${ }^{63}$ The multiplier effect of the location of a university had to be considered, not only in specifically employment terms but in social and cultural dimensions as well. This multiplier effect 'will be good if the area is one which it is the government's policy to 
develop, bad if it is already congested.' To aid this development, some of the costs of providing cultural or social infrastructure, such as libraries or theatres, that might make a new university more attractive or viable, could be included in more general regional improvement budgets. The Treasury advisors did not advocate establishing new universities solely in areas of deprivation and low employment, but they observed that 'it is difficult to accept as ideal the pattern of the eight universities founded since the war. ${ }^{64}$ Keele, York, Lancaster, Norwich and possibly Brighton could be justified, but probably not Colchester, Coventry or Canterbury, where any equivalent new venture would not receive an Industrial Development Certificate. Forwarding the report to the chairman of the UGC, the Treasury made it clear that the acceptability of any new proposals would depend a good deal on where they were located. ${ }^{65}$ Presented with a reality check, Murray maintained that they had taken a wide range of factors into consideration in the location of the last seven institutions, but that the regional dimension had been considered 'perhaps too indefinitely. ${ }^{96}$

In its discussion of the location of universities, the Robbins committee pointedly refrained from criticising the decisions made by the UGC but were as pointed that other considerations needed to be stressed in the formation of future policy. ${ }^{67}$ Chief among these was re-emphasising the claims of large cities where there were cultural amenities and access to industry, commerce, professional practice and government. Catchment reappeared as a possible way of managing the demand for halls of residence. Moreover was the benefit that a university could bring to a city. Nevertheless, Robbins was not keen on developing an explicitly regional organisation for higher education, preferring to maintain the distinction between locally-managed further and technical colleges and the autonomy of higher-level university institutions. An argument for the decision to locate the new universities where they were that appeared in both the Robbins report and the UGC's review of the period was that the CATs were mostly located in large cities, which would meet some of the demand for higher education in those places. This point did not feature highly in the private discussions of the UGC and may be something of a post-hoc rationalisation. As it turned out, Robbins' proposals for a further wave of new higher education institutions were not approved and there would be no new phase until the establishment of the polytechnics, with very clear connections to local factors. ${ }^{68}$

In the rapid evolution of policy on new universities, the UGC revised a century of previous thinking about the relationships between universities and the locality. Rescinding the idea of catchment meant there was no necessary connection between the requirements for 
higher education in an area and the location of a university. Thus, the new universities were not of or for their home towns, they were instruments of national educational planning that happened to be located in certain places. There was no sense of the regional dimension of national planning, or distributing facilities across the country. The UGC saw an opportunity to implement some of its ideas about university formation and merely sought places where they could be realised. It was soon disabused of this notion and regional considerations influenced the location of Lancaster. On the other hand, local support was still crucial. There had to be demonstrable civic, commercial and public support for a university before the UGC would consider an application seriously. Although it was noted that a university ought to contribute to local civic and community life, the relationship was essentially a parasitic one; the UGC was reluctant even to involve local personnel in planning discussions. Structural relationships between university and community, therefore, had an in-built separation and the key criterion of a large, green field site gave physical expression to the dissociation. The UGC's encouragement of student mobility added to the contradictions. Residence on campus was seen as important, although the UGC refused to provide the funds to build it, so another crucial factor in the location of a university was the availability of lodgings. This, however, implied a quite intimate connection between students and their host communities, pregnant with further tensions.

\section{University-civic connections}

How then, did the UGC policies play out in practice; what points of contact emerged between the new universities and their neighbouring towns? The next sections consider two aspects to the question, firstly the nature of more formal institutional relationships, and secondly the interactions between students and their neighbours. There is no space here for a comprehensive survey, so two places are taken as examples; the universities of Sussex and Lancaster. These were the first and last of the set to be recognised, with notable differences between them, alongside more fundamental similarities. The focus is on the early 1960s, when connections between the universities and their host communities were, arguably, most dependent. As noted above, the geographical location of the universities was based largely on the enthusiasm shown by localities. We start with this side of the equation before moving on to how universities repaid the compliment. 
Brighton claimed a long record of seeking university status, dating back to 1911 when proposals were put to the Royal Commission on the University of London to include Sussex within its orbit. ${ }^{69}$ The notion was accepted in principle, but plans were soon overtaken by the outbreak of war. The idea was re-visited fitfully through the 1920s and'30s, and then revived more seriously from the late 1940s. Although the UGC declared itself against new ventures outside north Staffordshire, the LEA for Brighton charged its director, W. G. Stone, with keeping abreast of debates about higher education and he discerned the patterns of trend and bulge that transpired through the 1950s. When the climate of opinion changed, then, Brighton was well placed to put forward its case. In concrete terms, Brighton Corporation gifted 145 acres on the northern edge of the city at a peppercorn rent of $£ 1$, and bought a further 50 adjoining acres. Local authorities across Sussex offered $£ 40,000$ a year to the project up to 1963 and $£ 58,000$ thereafter, while a public appeal raised approximately $£ 1$ million by the end of 1964. Up north, Lancashire boasted two of the pioneering civic universities in Manchester and Liverpool and there was little further movement until the north-west began to be touted as the location for the last of the new universities. Lancashire County Council seized the initiative and received two viable proposals. ${ }^{70}$ The coastal resort of Blackpool offered a large parcel of land in the central Stanley Park, a 3d rate and had famously plentiful lodgings. Just inland, the historic county town of Lancaster had been identified as a contender in Balchin's survey. Here, the local authorities investigated using a former mental asylum but, discerning the prevailing mood, quickly changed tack to scoop an offer for an undeveloped green field site just to the south of the city. When representatives from the LCC visited both potential sites they judged in favour of Lancaster, in part because the Stanley Park site in Blackpool already had planning permission for a large new leisure attraction. The park could have accommodated both schemes, but the ruling was in favour of placing the new university with an historic city rather than a brash seaside resort. The County Council offered $£ 50,000$ per annum for five years, while Lancaster City Council bought the land and re-drew its civic boundaries to bring the site within its compass. A public appeal was launched with the aim of raising $£ 2$ million. Thus, Lancaster and Brighton evidenced their commitment to hosting a university. Substantial parcels of land were handed over at nominal rents following considerable legal and diplomatic efforts to secure them. Important sums of recurrent income were offered and the public at large demonstrated their support not least through contributions to ambitious appeal campaigns. 
Starting from green fields, it would take some time before any of the new campuses were properly established so, in the early stages, local resources were drawn on extensively. Sussex started with only a handful of students housed briefly in the city centre, but the central building, Falmer House, was ready a year after the official opening and teaching was very quickly established on site. ${ }^{71}$ In many other respects the university depended on local facilities. Sporting societies relied on the good offices of neighbouring clubs and schools for playing fields. ${ }^{72}$ More central to academic life, Brighton Public Library trebled its book fund over five years and expected to purchase a further 100,000 to 200,000 books over the next 15 years. ${ }^{73}$ The library revised its lending arrangements to serve academic requirements, although the books were available to the general public as well. Lancaster University had an unusually close connection with the city in its early years. The City Council acquired the buildings of the old furniture firm Waring and Gillow for commercial development, but offered them first to the university, thus allowing it to admit students much more quickly. ${ }^{74}$ Indeed Lancaster University welcomed its first students before several of the others that had started sooner. For several years, the university was effectively located in the city centre; lectures were delivered in a local church and other teaching and social facilities were housed in the old warehouse. ${ }^{75}$ These arrangements made the development of the permanent site a little less pressured, but there was a clear disengagement from the city when, after a few years, the university moved, quite literally, out of town.

Civic commitment and public generosity were vital in founding the new universities and nurturing them through initial years of dependency. No doubt, acquiring the status of a university town was appealing, but it was generally acknowledged that hosting a university should have some more material benefit for the town. Despite local generosity, however, there was great reluctance to include local representatives in university planning or direction. Stone's participation in the Academic Planning Board for Sussex was a conspicuous exception. ${ }^{76}$ Civic dignitaries were given only a symbolic role on governing bodies, appearing for graduations and ceremonial functions. Both Sussex and Lancaster vicechancellors established town-gown organisations to try to promote relationships, but both bodies seem to have declined into occasional dining clubs with only limited useful purpose. ${ }^{77}$ To be fair, quite what towns expected of a university was rarely articulated precisely. Stone's account details the strenuous efforts made by the Corporation to bring a university to Brighton, but does not explain why. Shortly after its foundation, a comprehensive review of the impact of the university, and other higher education institutions, on Brighton was 
compiled. ${ }^{78}$ It was calculated that $£ 21 / 2$ million in capital expenditure had been spent on buildings, with a further $£ 1$ million on professional fees, furniture and equipment. In the construction of the campus, three contractors mainly employed local men with 282 out of 361 engaged being from the area. Sixty people were employed in the Catering Department, but the large contracts were served by two London firms. It was estimated that the university in general spent about $20 \%$ of its total expenditure locally, while students spent almost all of theirs. A major impact of the universities on the local economy was through lodgings. In Brighton, it was noted that the influx of students primarily during the winter months had helped to stabilise the guest house sector with more permanent employment, although there were some additional costs as well in catering for the different needs of students. We shall return to some of the other impacts of students in lodgings further below. Academic staff were more likely to be incoming, but permanent residents. Just over $40 \%$ of staff at Sussex lived in Brighton itself, with a sizable $30 \%$ residing in the Lewes area, having more of an impact on a relatively smaller place. Academics spent about $75 \%$ of their income locally and all year round.

Lancaster's vice-chancellor, Carter, was quite explicit in courting commercial interests, with his first public speech given to the Chamber of Commerce in the Town Hall. ${ }^{79}$ He presented a vision of rapid growth to about 3,000 students with 350 teaching staff, 200 technicians, 300 domestic and miscellaneous staff, plus the help of almost 1,000 landladies, altogether bringing an estimated $£ 2$ million a year into the city. Launching a public appeal, it was emphasised that the university could be a locus for regeneration. ${ }^{80}$ Pricking local conscience, it was argued that wealth flowed more readily to the south, which already had the predominance of cultural and educational facilities. The university could help to redress the balance, but only with particularly generous support. Carter was sometimes torn between his gratitude for the extent of local support and his desire for wider academic recognition. In a magazine article, he acknowledged; '[w]e thus have a special reason to remember with gratitude the willingness of the people of north-west England to come forward to create a national university. ${ }^{81}$ Elsewhere, he emphasised that the primary role of a university was as a place of teaching and research and a model of corporate life, albeit helped by local funds. ${ }^{82} \mathrm{~A}$ hint of underlying tension surfaced in a brief spat when the university proposed hosting residential conferences on campus. ${ }^{83}$ This was seen as direct competition to the local guest house sector and the press, usually very supportive of the university, took it to task. A rather hurt response from the university objected to the implicit view that its only benefit was 
commercial. The newspaper reiterated its appreciation of the cultural benefits of hosting a university, but did not withdraw its view that the area also expected a more material return.

Quite how the new universities could make such a return was not obvious. At the civic universities, one of the most conspicuous means by which they contributed to their localities was by providing services to industry, through training, consultancy or research. ${ }^{84}$ Here, the changing landscape of post-war higher education militated against laudable intentions. ${ }^{85}$ Further and higher technical education had been extensively reviewed and reorganised in the post-war years. At considerable expense, the most developed technical colleges in major centres of industry were elevated to become Colleges of Advanced Technology, while a second tier was recognised as regional centres. The older established universities also received substantial injections of funds. The UGC was not keen, then, on the new universities also setting up expensive facilities for applied science. Some did manage to forge links with industry, most notably Warwick, although this presented a singular case. ${ }^{86}$ There had been proposals to connect the new university with the technically advanced Lanchester Technical College, but government agencies refused to allow this to take place and a more coherent development in Coventry did not transpire. Essex, too, made greater efforts to reach out to industry and also, as we shall see, Lancaster. ${ }^{87}$ Similarly, the organisation of teacher-training had been exhaustively re-modelled with only limited connections to the university sector. As the binary divide came into force, it became even more difficult to connect different parts of higher education together. ${ }^{88}$ Another prominent feature of the civic universities were important medical schools, integrated with local hospitals and public health services. ${ }^{89}$ Again, medical education had been reviewed after the war and there was no question of medical schools being established at any of the new universities.

Sussex University certainly struggled to engage with industry. ${ }^{90}$ There was already a thriving technical school in Brighton, indeed when proposals for a university were first mooted, it was thought to base it on the technical school. ${ }^{91}$ The plan for a separate university scheme devised in the late 1940s meant that the two institutions sat adjacent to each other. With a relatively limited industrial base in the county, it was unlikely that a major technical facility would be developed at the university as well. Looking back, Vice-chancellor Briggs was sensitive to the view that the new universities ignored economic aspects of their role and claimed to have sought to establish an applied sciences facility. ${ }^{92}$ As some measure of recompense, Sussex established short courses of in-service training. ${ }^{93}$ In other respects, there 
were attempts to link university expertise to local issues, such as through socio-educational research. A raft of other social research issues such as leisure, ageing, social change, communications and new town development were also identified as alternative ways by which the university could mobilise its expertise on matters of local and national importance.

In this respect, the situation in Lancaster was noticeably different. By the time of its foundation in a region where it was felt that there was a lack of higher education, there was a greater recognition of the economic role a university should play, and this aspect featured more prominently in how the university presented itself and its academic profile. Admittedly as part of an appeal for funds, a section on 'Planning for the Needs of Industry' itemised a series of initiatives to achieve that end, including Operational Research, Industrial and Regional Economics, Marketing and Statistics. ${ }^{94}$ A Department of Materials Science was envisaged, and research on the utilization of natural resources, transport problems, industrial biochemistry and organic chemistry. While academic under-pinning was important, general training had to be combined with preparation for specific tasks. Building on this ethos, a distinctive initiative was the formation of Enterprise Lancaster. ${ }^{95}$ This emerged out of discussions of the Town and Gown Club and was intended to attract small high-tech industries to Lancaster. A co-ordinator was provided jointly between the city and the university, with an office in the town hall. When the central city site was vacated, it was used by the council for seed-bed development of small firms. In the early 1970s, a new scheme invited suggestions from small businesses for discrete research projects to be conducted by the university. Each year a few were selected, paid for out of a research fund donated by local authorities. Neither of these ventures were a major component of Lancaster's work, but they are indicative of a changing tone when it was established, and tacit criticism of absences elsewhere.

Traditionally, a prime vehicle for academic engagement with the local population was extra-mural education, but both Sussex and Lancaster faced several obstacles. In part, extramural work was already in place. In the county of Sussex, the Oxford Delegacy and the University of Southampton had a well-developed presence, sometimes involving Sussex University staff. ${ }^{96}$ Briggs also identified a structural problem in that the whole curricular ethos was to break down departmental divisions in favour of a schools of study arrangement. Thus, it did not make sense to establish a distinct extra-mural department. Rather optimistically, he argued that all that was needed was a budget, administrative support and a conception of an 'Extra-mural University' drawing on all the schools. The collective 
enterprise would be underpinned by the School of Education, which had a more explicit brief to engage with the community and bring activities together. These high-minded ideals took some time to reach fruition, partly because the UGC refused to sustain the budget component of the equation and, it appears, the university itself did not live up to the rhetoric. ${ }^{97}$ A Centre for Continuing Education was finally launched in 1969 when the Oxford Delegacy transferred its responsibilities in the area to Sussex. A similar story prevailed at Lancaster, without even a belated entry to the field. ${ }^{98}$ Discussions with existing providers from Liverpool, Leeds and Newcastle, and a reluctant UGC continued into the 1970s with the result that extra-mural work failed to materialise in the first decade. In one sense, Briggs was right because academics did not need formal structures to engage with their local communities and there is plenty of evidence of informal contact through a range of talks, lectures and study events. As the professors were appointed at Lancaster, their inaugural lectures were held in public at town-centre locations. ${ }^{99}$ Staff members addressed Rotary organisations and civic societies, university chaplains held open lectures on campus and a conference on Race and Racialism was open to the public in town.

A more tangible means by which a university could contribute to the life of the community was by providing additional cultural facilities and both of our institutions recognised this as important. Although there were other immediate priorities, it was not long before there were plans for artistic centres. Lancaster's first seven-year plan envisaged music practice and performance spaces and a theatre, seen as a service to Lancaster and surrounding area. ${ }^{100}$ There were proposals for a joint city theatre in Lancaster from 1965, ultimately resulting in the Dukes Playhouse opened in 1971. ${ }^{101}$ A Centre for Visual Arts on campus opened a year later. At Sussex, a generous donation from the Gulbenkian Foundation paved the way for the Gardner Centre, which became a concrete point of contact between the university and the community. ${ }^{102}$ There was debate in both Lancaster and Brighton about the proper role of such a centre and the conclusion was the same; that they were for more experimental and art-house ventures, not to compete with local entertainment enterprises. ${ }^{103}$ Arts Centres emerged as one of the flagship avenues by which the new universities added to the cultural life of their communities.

\section{Students and their neighbours}


The most immediate and intimate point of contact between the new universities and their host communities was via the students, who found themselves as neighbours to local residents for at least some of their university career. As argued above, a quite contradictory situation emerged at the new universities. The UGC had been promoting halls of residence as a central feature of the university experience from the 1930s and the new institutions offered an ideal opportunity to incorporate halls into model academic communities. Halls of residence, however, were very expensive to provide and the UGC was decidedly reluctant to pay for them. Consequently, one of the main criteria used in determining the location for a new university was the availability of lodgings. ${ }^{106}$ Hence, a novel population of young men and women would descend on relatively smaller towns and cities, living cheek by jowl with locals; a situation fraught with potential problems, although also some important advantages. This section will make a brief, illustrative survey of some of the ways in which students related to their neighbours.

Brighton was a seaside resort with plentiful guest houses that could accommodate students in the fallow winter months. In the early 1960s, the university block-booked all available accommodation in conjunction with the Brighton and Hove Hotels and Guest Houses Association. ${ }^{107}$ In 1962/63, 301 out of 414 students were accommodated in guest houses rising to 600 out of 1,624 three years later. The university appointed a Junior Dean to take care of disciplinary matters relating to students living in town and a Senate Disciplinary Committee was established. ${ }^{108}$ In the first year of its operation, a number of relatively minor problems were brought to the committee, generally relating to issues of noise and poor behaviour among a small number of students, grating against the confines of their lodgings. ${ }^{109}$ At the beginning of the following year, a more formal structure was established to negotiate relationships between the university and the guest house sector with clearer guidelines. ${ }^{110}$ Proprietors were responsible for the good order of their houses but were to report persistent problems to the university's disciplinary officers. At a joint meeting, rents, meals at weekends, utility charges and other matters were thrashed out. ${ }^{111}$

A prime point of contention was the entertainment of guests in students' rooms. ${ }^{112}$ University representatives saw this as an important element of undergraduate life, mirroring the freedoms of a hall of residence; guest house proprietors were less sanguine, especially if there were several visitors and certainly if they were of the opposite sex. A 'Visitors' Clause' in the joint agreement with the University allowed guests up to $11 \mathrm{pm}$, and for residents to sign out if they were to be out late. Serious incidents seemed rare, but one was brought to a 
specially convened meeting to consider a case which had led to the exclusion of nine students. One account suggested that the matter was so serious that it might have led to the prosecution of the landlord for keeping a disorderly house. The university was sceptical and maintained the right of students to meet together as they wished as responsible members of the community. Proprietors were reminded that if problems arose, there were procedures for dealing with them and it was always open to them to withdraw from the scheme. Met with reasonableness and resistance, the guest house owners accepted that the existing Visitors' Clause should remain. Although supportive of the freedoms of its students, the Disciplinary Committee did impose sanctions for clear infringements. ${ }^{113}$ Four men were collectively fined 20/- for continually behaving in a noisy and irresponsible manner. A somewhat more hefty fine of 10/- was imposed on a woman for being away all night without signing out.

Lancaster was not a tourist town, but was accessible to the hotels and guest houses of neighbouring Morecambe and the vice-chancellor made an early appeal to its landladies. ${ }^{114}$ After some initial caution, Morecambe became home to the early arrivals at the new university, and the sector was quick to defend its interests when the university seemed to threaten its position. ${ }^{115}$ An issue that emerged through the middle of the decade was the growing desire of students to live independently in flats, without any of the restrictions of halls of residence or guest house lodgings. ${ }^{116}$ This was of concern to the landladies who feared an exodus from their lodgings and for the university as a disciplinary matter. The university gradually allowed final year students and then second years after Easter to take up flats. Since this effectively limited the potential numbers, the landladies were mollified, although it was reported that the moves still put pressure on the flat sector in Lancaster.

Relationships between students and their neighbours were frequently discussed and generated plentiful anecdotes. Student newspapers complained that guest house life militated against a university feel; Sussex students were distributed across Brighton and Lancaster ones faced the daily commute from Morecambe. ${ }^{117}$ There were criticisms about a lack of social amenities in provincial towns not geared to a burgeoning youth audience while campus development focussed on basic academic infrastructure. Resourceful undergraduates, however, found plenty to occupy their time. Some mutual animosity was reported as students found the locals critical and unfriendly, and locals regarded students as noisy and aloof. Problems more easily found their way into the press. Sussex in particular, as the pioneering new university and within easy reach of the national press, often felt that it was subject to frequent, sometimes intrusive and commonly prurient media interest. ${ }^{118}$ In one unguarded 
moment, the head of the university's medical centre, speaking at a medical conference in London noted the availability of contraceptive advice at the university. ${ }^{119} \mathrm{He}$ had found the students seeking it to be responsible and seldom permissive, indeed less so than nonuniversity counterparts. This, however, was reported in the local paper under the heading 'Wise non-virgins of Sussex University'. Recognising the faux pas, the speaker immediately sent a copy of the newspaper clipping to the Vice-chancellor with an apology; he had not known there were press in the conference or he would have avoided any potential headline phrases.

Lancaster was less likely to draw the attention of the national press and was fortunate in its local coverage. The Lancaster Guardian had a regular column of 'University Notes' and reported frequently on the development of the campus and activities going on there and in town. ${ }^{120}$ Less savoury incidents, however, were reported on. A common bug-bear of student-town relationships was RAG week. Aware of the sensitivities, the organisers of the 1966 event sought to allay fears from an early date, promising to avoid annoying stunts and there seem to have been no major incidents. ${ }^{121}$ The following year's event, however, descended into a flour-fight on the streets, which was discussed in the council chamber and for which the vice-chancellor had to issue an apology. ${ }^{122}$ This came close after another altercation between a group of students and the bus company after a Bonfire Night party. ${ }^{123}$ Contrary claims as to what exactly took place were rehearsed in the press to the good report of nobody. As an indication of times to come, several students found themselves falling foul of the law, some following an unauthorised protest against the Vietnam War and others after a drugs raid by the police on several flats in Lancaster and Morecambe. ${ }^{124}$

Political activism could also take more conventional forms and an influx of enthusiastic young people was welcomed as having a beneficial effect. In Brighton, there was some debate as to whether a largely left-leaning student population had helped the Labour Party candidate to election victory in the Kemp Town constituency. ${ }^{125}$ A report by the university bulletin suggested that the Labour Party campaign was boosted by the assistance of 26 staff and 90 students, whereas the Tory candidate had only three members of staff and 30 -40 students. Apparently there had been no difficulty with integrating the work of local with university helpers. It was inconclusive whether university members had made the difference (a similar swing to Labour had occurred in a neighbouring constituency without much university representation) but it was noted that the presence of the university had invigorated local political organisations. Although on the losing side, the Conservatives had particularly 
welcomed the additional help and felt that greater involvement in political activity was generally a good thing. In Lancaster, the student political groups attracted some headline speakers, such as Merlin Rees, Minister of State for Defence. ${ }^{126}$ Members of staff became active contributors to the civic society, urging the city to make more of the cultural and economic heritage of the city. ${ }^{127}$ Culturally, too, students could make a valuable contribution to the life of their communities. The Lancaster University Theatre group performed in the town's Grand Theatre and, for its inaugural production performed an ambitious double bill of Pinter's 'The Dumb Waiter' and a sixteenth century romp 'Gammer Girton's Needle' in contemporary English. ${ }^{128}$ The local newspaper applauded the ambition and welcomed the proposal for joint ventures with local groups. The Sussex University Review 'Twilight Zone' was as ambitious, but with a less happy outcome. A member of the audience complained to the vice-chancellor about some religious allusions and the complaint escalated into the orbit of the Lord Chamberlain. ${ }^{129}$ Some strongly worded letters and grovelling apologies smoothed over the situation. ${ }^{130}$ Nevertheless, student groups were keen to involve themselves in local cultural life, often bringing more experimental and avant garde productions to provincial audiences.

Students were at least as keen to devote their energies to working with people less advantaged than themselves as to flout social norms or make a nuisance of themselves. In both Lancaster and Brighton, students volunteered huge amounts of time to social projects in town. Children's playgrounds were popular and established in both places. ${ }^{131}$ An account of the Moulescoomb scheme in Brighton acknowledged that there were difficulties in harnessing the energies of untrained and unpractised youngsters generally only available at certain times of the year, but their efforts had led substantially to the building of a playground in one of the most deprived parts. ${ }^{132}$ In a wonderful observation it was recorded that volunteers 'walk up Moulescoomb Way to give and return home embarrassed by what they receive.' The range of different projects listed in just one pamphlet offers a spectrum of work in which students were involved, including hospital and prison visiting, lighting fires for older people when regular social services were not available, decorating rooms for those unable to do it for themselves, reading to the blind or helping out at an approved school. ${ }^{133}$ It is unclear what proportion of the student population engaged in such activities, which could easily be over-shadowed by more negative aspects but, in myriad ways socially, culturally and economically, students made a difference. 


\section{Conclusions}

In the mid-1950s, UGC policy on university development remained in early twentiethcentury mode, nurturing likely institutions towards maturity in a tradition of locally-oriented development. Brighton was approaching the end of its pupillage and there seemed no need for any further expansion in the near future. As targets for student numbers were dramatically raised, and assumptions about the appropriate size of universities remained the same, UGC thinking changed rapidly to creating a whole wave of fully-fledged universities with ambitious academic, educational, architectural and social aspirations. Enjoying virtual carte blanche, the UGC seized the unprecedented opportunity to fashion model academic communities in inspirational settings and re-think disciplinary norms. The ideas had been nurtured from the 1930s, through emphasising halls of residence and a rounded student experience. Students responded accordingly and mobility steadily increased through the postwar period. Abandoning the principle of catchment recognised the realities, but also removed an essential requirement for universities to cater for the needs of their geographical location and, thus, a central component of the relationships between universities and communities that had been in place for a century. In common with other aspects of educational planning, the UGC articulated the issue as growing national demand for higher education, while better communications and an emphasis on residence, meant that both universities and the student cohort could be seen as part of a national estate. Nevertheless, the UGC still insisted on local support. Understandably, it was not prepared to establish a university where it was not wanted, or where there were no appropriate cultural resources, but it made for an unequal relationship, lacking reciprocity. The new universities were seen as instruments of national policy, serendipitously, perhaps parasitically, accommodated with generous and supportive hosts.

Although the UGC enjoyed freedom of action within its own domain of university development, it was also constrained by the wider expansion of higher education since the war, which also served to remove connections that had become the norm under the civic model. One of the mainstays of the civic universities was medical education, but this was reviewed and developed separately, and there was little scope for establishing expensive medical schools at the new universities. Another linchpin, teacher-training, was also being reorganised apart from the university system. Similarly, formal adult education was already being catered for, although academics found other ways of contributing to the cultural life of their towns. Technical education presents a more mixed record. This too had already been 
reorganised and considerably expanded, making the development of applied science and potential connections between the new universities and industry less necessary and less possible. Some institutions did make meaningful connections, although others struggled. In our two cases, Sussex lamented the limits of its achievements, although Lancaster, founded in a somewhat different context, did make a more concerted effort. One of the principal means by which the new universities provided for their regions by the end of the decade was through establishing Arts Centres. Higher education policy in general, and UGC attitudes in particular, served to separate the new universities from their communities, undermining the civic ideal and casting them as essentially liberal arts colleges set apart on the outskirts of town.

Paradoxically, one outcome of abandoning catchment areas in fact brought universities into very direct contact with their neighbours. If students came from across the country, they needed somewhere to live and, for all the UGC lauded halls of residence, it was contrarily reluctant to pay for them, and so lodgings became critical. Students living in lodgings was not new, but an influx of young people from outside the area into relatively small towns presented a novel experience for those places. The problems were, and have been, well-rehearsed. Students could be noisy, anti-social and aloof, locals could be disparaging and unwelcoming. Equally, students helped to promote cultural and sporting endeavour, brought new life and vigour to social and political life and enthusiastically supported worthwhile community projects. It is curious that, in UGC thinking and subsequent historical analysis of innovative academic communities, there has been so little consideration given to the circumstances in which most students would spend a good proportion of their university lives. More or less salubrious guest houses, the local pub, chippy and launderette were, arguably, the dominant environs for students at the new universities. This component of universities' engagement with their communities has become ever more pervasive as the trend towards student mobility underpinning a national student estate and university system continued through the second half of the twentieth century, more recently exacerbated by mass higher education. Probably, it is the dominant trope of the university experience and town-gown relationships, although patterns have varied. Some institutions have remained more regionally-focussed and the assumption of going away to university may be faltering. ${ }^{134}$

The 1960s universities have been rightly recognised as a unique academic phenomenon. Not again would a set of institutions be created de novo with such resources and innovatory ideals; nor would the UGC be given virtual carte blanche to indulge in such 
academic experiments. Similarly, severing the link between universities and localities seems also to have been a short-lived experiment. Robbins re-affirmed the importance of universities engaging more directly with larger and lively urban communities. The longestablished principle of expecting universities to contribute to economic well-being, primarily of their regions, was re-affirmed. Robbins' proposed further wave of higher education institutions did not transpire. What did come to pass was the polytechnic movement, which very clearly connected higher education with civic enterprise, in local-authority controlled institutions. Not that the relationships between university and community are generally unproblematic. Town versus gown may be a cliché, but nonetheless captures an underlying tension. Universities have become a global phenomenon, locked into international networks and, in principle, academic knowledge is universal. Yet, for the most part, universities are located in, and dependent on, particular places, leaving enormous footprints. Despite the potential problems, localities have overwhelmingly welcomed universities, for the cultural enhancement and educational opportunities they offer, for the spending power of staff and students and the economic possibilities of knowledge and innovation, as well as the prestige of being a university town. Universities seem more ambivalent, drawn to the siren appeal of international status yet, normally, unable to escape their localities and all too ready to highlight the attractions and advantages of their situations, the opportunities for real-world experience and research impact.

\footnotetext{
${ }^{1}$ Beloff, Plateglass Universities; Carswell, Governments and the Universities; Stewart, Higher Education in Post-war Britain; Muthesius, Post-war University; Tight, Development of Higher Education; Whyte, Redbrick. There were parallel developments in other parts of the UK, and across the globe.

${ }^{2}$ Halsey, 'British Universities and intellectual life'; Trow, 'The idea of a new university'; Cross and Jobling, 'The English new universities'; Perkin, New Universities.

${ }^{3}$ Perkin, New Universities, p. 213.

${ }^{4}$ Armytage, Civic Universities; Sanderson, Universities and British Industry; Jones, Origins of Civic Universities; Anderson, British Universities; Vernon, Universities and the State; Whyte, Redbrick.

${ }^{5}$ Vernon, Universities and the State
} 
${ }^{6}$ Edgerton, Warfare State; Ortolano, Two Cultures; Salter and Tapper, State and Higher

Education; Tight, Development of Higher Education. Although most note that the main drive towards economic development and state control came with Robbins, after the advent of the new universities.

${ }^{7}$ Gallie, New University; Kolbert, Keele.

${ }^{8}$ Perkin, New Universities.

${ }^{13}$ Beloff, Plateglass Universities; Carswell, Governments and the Universities; Stewart, Higher Education in Post-war Britain; Tight, Development of Higher Education;

${ }^{14}$ Sanderson, Universities and British Industry.

${ }^{16}$ Vernon, Universities and the state

${ }^{17}$ Shinn, Paying the Piper.

${ }^{18}$ Shattock, $U G C$.

${ }^{19}$ Kolbert, Keele

20 'New University Institutions in Britain', 4 March 1959. UGC7/169. [All UGC files used here are held at the National Archives].

${ }^{21}$ Letter to Mr Maurice Edelman MP, 10 December 1958. UGC7/169.

${ }^{22}$ Note by E. R. Copleston [UGC], 14 April 1959. UGC7/169.

23 'UGC Sub-committee on New University Colleges', Paper NUC/2/59, 27 May 1959

(Annex 3). UGC7/169.

24 'Sub-Committee on NUC.' Minutes NUC/1/59, 21 May 1958. UGC7/169.

${ }^{25}$ Letter from the Principal University College Sussex to UGC, 17 September 1959. 'Subcommittee on New University Colleges'. Minutes NUC/3/59. 16 December 1959. UGC7/169. 26 'Sub-Committee on NUC.' Minutes NUC/1/59, 21 May 1958. UGC7/169.

${ }^{27}$ Vernon, Universities and the state

${ }^{28}$ Returns from Universities and University Colleges in Receipt of Treasury Grant, 1919-20 [Cmd. 1263]. The figures are averages and relate to the universities of Birmingham, Bristol, Leeds, Liverpool, Manchester, Sheffield and Armstrong College, Newcastle-upon Tyne. There is no indication of know how many of those living in lodgings were also local people. ${ }^{29}$ UGC Report for the Period 1929/30 - 34/35 [HMSO, 1936].

${ }^{30}$ Beloff, Plateglass Universities; Edgerton, Britain's War Machine; UGC, Annual Report, 1950-51. (HMSO, 1951); UGC, University Development 1957-62 [Cmnd. 2267].

${ }^{31}$ UGC returns for the Year 1950-51 [Cmd. 8638].

32 'Sub-committee on New University Colleges', NUC/5/59. 14 October 1959. UGC7/169. 
${ }^{33}$ Vernon, 'A healthy society for future intellectuals'.

${ }^{35}$ UGC, Report of the Sub-committee on Halls of Residence. (HMS), 1957); Silver, Opinion Making.

${ }^{37}$ This point on the list of geographical factors to be considered was marked with a large ' $\mathrm{X}$ '

${ }^{39}$ Beloff, Plateglass Universities; Stewart, Higher Education in Post-war Britain. The growing perception of a need for more university places was based primarily on the demographic factors of the trend towards more of the relevant age cohorts wanting to go to university and a bulge in the post-war population.

40 'Sub-committee on New University Colleges', Paper NUC3/59. 14 October 1959. UGC7/169.

41 ‘Annex II. Note of Chairman's visit to York 24 June 1959. 'Sub-committee on New University Colleges', 14 October 1959. UGC7/169.

${ }^{42}$ Emphasis in original.

43 'Sub-committee on New University Colleges', Paper NUC4/59. 14 October 1959.

'Consultations with interested parties.' UGC7/169.

44 'Sub-committee on New University Colleges'. Minutes NUC/2/59. 14 October 1959. UGC7/169.

45 'Note of a meeting at the Treasury', 22 December 1959. UGC7/170.

46 'Sub-committee on New University Colleges'. Minutes NUC/2/59. 14 October 1959. UGC7/169.

${ }^{47}$ Beloff, Plateglass Universities.

${ }^{48}$ Letter to Murray [UGC], 28 March 1961. UGC7/174.

49 'New University Institutions. Memorandum by the University Grants Committee'. March 1960. UGC7/170.

50 'New University Institutions'. March 1960, p. 3-4.

${ }^{51}$ W. G. V. Balchin, 'University Expansion in Great Britain’ New Scientist 12 March 1959

${ }^{52}$ Correspondence between Murray and Eversley 25 April to 12 May, 1960 UGC7/170. It is unclear who made the first contact.

${ }^{53}$ Eversley to Murray 27 April 1960. UGC7/170. Emphasis in original.

54 ‘The Gulbenkian Educational Discussions 1960'. Universities Quarterly 15 (1961). In 1960 the Calouste Gulbenkian Foundation agreed to support an annual conference organised under the auspices of the journal, of 'top people' who could make a difference to the development of major educational plans. The inaugural conference was on new universities. 
${ }^{55}$ Letter from Mary Smieton [Ministry of Education] to Murray. 23 January 1961. UGC7/171.

${ }^{56} \mathrm{We}$ shall return to this issue later.

57 'Report of the Sub-committee on New University Institutions'. Minutes 26 Jan 1961. UGC7/171.

58 'Sub-committee on New University Colleges'. Minutes 25 January 1961. UGC7/171.

${ }^{59}$ Letter from Vick [Member New University Colleges Sub-committee] to Murray. 23 Jan 1961 UGC7/171.

${ }^{60}$ Letter from Copleston [UGC] to J. A. C. Robertson [Treasury]. 21 July 1961. UGC7/171.

${ }^{61}$ Copleston to G. W. Moseley [Treasury]. n. d. UGC7/171.

${ }^{62}$ McCrone, Regional Policy.

${ }^{63}$ R. W. B. Clarke, 'The Location of New Places of Higher Education’ 25 July 1963. UGC7/171.

64 'The Location of New Places of Higher Education', p. 4. UGC7/171.

${ }^{65}$ Clarke to Murray 29 July 1963. UGC7/171.

${ }^{66}$ Murray to Clarke 1 Aug 1963. UGC7/171.

${ }^{67}$ Report of the Committee on Higher Education [Cmnd. 2154] (HMSO, London; 1963)

${ }^{68}$ Shattock, Making Policy.

${ }^{69}$ Stone, 'Steps leading to the foundation of the university'.

${ }^{70}$ McClintock, University of Lancaster.

${ }^{71}$ Briggs, 'The Years of Plenty'.

72 'Sports Pavilion Opening Ceremony’ Memorandum from M. J. Batchelor 13 May 1966.

SxUOS1/1/1/17/12. [University of Sussex archives are kept at the Sussex County Records Office]

73 'Effect of the University of Sussex on the Town of Brighton' (1965) [Pamphlet held at the University of Sussex Library]

${ }^{74}$ Lancaster Guardian 28 June 1963. [A collection of 'Press Cuttings Illustrating the Growth of the University of Lancaster' is held in the university's special collections.]

${ }^{75}$ McClintock, University of Lancaster.

${ }^{76}$ The chairman of the Norwich Academic Planning Board, who was opposed to local involvement, acknowledged that Stone was admirable, but may have set the wrong precedent. Letter from 'Bill' to Murray, 28 March 1961. UGC7/174.

${ }^{77}$ McClintock, University of Lancaster. Perkin, New Universities. 
78 'Effect of the University of Sussex'

${ }^{79}$ Lancaster Guardian and Observer 29 Mar 1963 [Press Cuttings]

${ }^{80}$ The University of Lancaster. The First Seven Year Plan 1964-1971 [Lancaster University Special Collections].

${ }^{81}$ C. F. Carter, 'On Founding a University’ Progress 49 (1962): 194-198, p. 198.

${ }^{82}$ C. F. Carter, 'A message from the Vice-chancellor' in The University of Lancaster.

Lancaster Guardian Special Supplement 1964.

83 'The Visitor and the University' Lancaster Visitor 21 June 1967. [Press cuttings]

${ }^{84}$ Sanderson, Universities and British Industry. Vernon, 'Civic universities and community engagement'.

${ }^{85}$ Shattock, Making Policy.

${ }^{86}$ Shattock, UGC. Sanderson, Universities and British Industry

${ }^{87}$ Sanderson, Universities and British Industry.

${ }^{88}$ Shattock, Making Policy.

${ }^{89}$ Vernon, Universities and the State.

${ }^{90}$ Sanderson, Universities and British Industry. Shattock, Making Policy. Perkin, New

Universities.

${ }^{91}$ Stone, 'Foundation of the university'

92 Briggs, 'Years of Plenty'

93 'University of Sussex The Quinquennium 1967-1972. Papers submitted to the UGC', November 1966. SxUOS1/1/1/17/12.

${ }^{94}$ University of Lancaster, The First Seven Year plan.

${ }^{95}$ McClintock, University of Lancaster.

96 Sussex 'Quinquennium'.

${ }^{97}$ Smith, 'The impact of the University on the local community'.

${ }^{98}$ McClintock, University of Lancaster.

${ }^{99}$ See for example, Lancaster Guardian 20 May 1966, 29 October 1968. [Press cuttings]

${ }^{100}$ University of Lancaster, The First Seven Year plan.

101 'A message from the mayor' Lancaster Guardian Special Supplement October 1967.

[Press cuttings]. McClintock, University of Lancaster.

102 Sussex 'Quinquennium'

${ }^{103}$ Smith, 'Impact of the university'. 'University and town' Lancaster Guardian Special Supplement, October 1967. [Press cuttings]. 
106 'Sub-committee on New University Colleges', NUC/5/59. 14 October 1959. UGC7/169. It was highly ironic that the bulk of painstakingly raised public appeals were devoted to building halls of residence for students from outside the town.

107 'Effect of the University of Sussex'

${ }^{108}$ Sub-committee regarding disciplinary matters, minutes 24 April 1962. SxUOS1/1/1/17/23.

${ }^{109}$ Sub-committee regarding disciplinary matters, minutes 11 December 1962.

SxUOS1/1/1/17/23

${ }^{110}$ Sub-committee regarding disciplinary matters, minutes 16 January 1963.

SxUOS1/1/1/17/23

${ }^{111}$ Notes of meeting between representatives of Guest Houses Association and University Officers 8 April 1963. SxUOS1/1/1/17/23

${ }^{112}$ Minutes of meeting between representatives of Brighton and Hove Hotels, Guest Houses and Restaurants Association and University Officers 6 September 1963. SxUOS1/1/1/17/23 ${ }^{113}$ Student Disciplinary Officers' Report 16 Feb - 13 March 1964. SxUOS1/1/1/17/23. ${ }^{114}$ Lancaster Guardian and Observer, 29 March 1963. [Press cuttings].

115 Lancaster Guardian, 18 October 1963. [Press cuttings]. See above on the dispute over the plans to accommodate visitors on campus during the vacations

${ }^{116}$ Lancaster Guardian 26 October 1965; 19 January 1966; 9 February 1966. [Press cuttings]. ${ }^{117}$ See for example, The Wine Press 13 May 1966; 28 January 1965. SxUOS1/1/1/17/21. Lancaster Guardian University of Lancaster Supplement 25 June 1965. [Press cuttings]. 118 Smith, 'Impact of the university' 119 'Wise non-virgins of Sussex University’ Evening Argus 25 October 1966 and accompanying letter. SxUOS1/1/1/17/21

${ }^{120}$ There is no indication of how selective the collection of Press Cuttings held at the University of Lancaster is. It appears quite comprehensive and is predominantly, although by no means exclusively, positive.

${ }^{121}$ Visitor 9 February 1966. RAG weeks were long a focus of tension, Dyhouse, Students. 122 [No title] 15 March 1967; 5 April 1967. [Press cuttings].

${ }^{123}$ [No title] 9 November 1966. [Press cuttings].

${ }^{124}$ [No title] 23 November 1966; Visitor, 15 March 1967. [Press cuttings].

125 ‘The University and the Election’ University of Sussex Bulletin 29 Nov 1964

SxUOS1/1/1/17/21

${ }^{126}$ Lancaster Guardian, 15 May 1966. [Press cuttings]. 
${ }^{127}$ Lancaster Guardian, 29 October 1965. [Press cuttings].

${ }^{128}$ Lancaster Guardian, 26 November 1965. [Press cuttings].

${ }^{129}$ Letter from C. \& V. Whale to Principal, Brighton University 6 December 1962.

SxUOS1/1/1/17/21.

${ }^{130}$ Letter from D. Ackland (secretary Revue Society) to Comptroller (Lord Chamberlain's Office) n. d. SxUOS1/1/1/17/21.

131 'Up Moulescoomb Way’, December 1966. SxUOS1/1/1/17/21. Lancaster Guardian, 23

April 1966. [Press cuttings].

132 'Up Moulescoomb Way'. SxUOS1/1/1/17/21.

133 'Voluntary Service News', 1967. SxUOS1/1/1/17/21.

${ }^{133}$ The Guardian 4 September 2013 


\section{Bibliography}

Anderson, R. D., British Universities. Past and Present. London: Hambledon Continuum, 2006.

Armytage, W. H. D., Civic Universities. Aspects of a British Tradition. London: Ernest Benn, 1955.

Beloff, M., The Plateglass Universities. London: Secker and Warburg, 1968.

Briggs, A., 'The Years of Plenty, 1961-1976' in The Sussex Opportunity. A New University and the Future, edited by R. Blin-Stayle and G. Ivey, 1 - 21. Brighton: Harvester Press, 1986.

Carswell, J, Governments and the Universities in Britain. Programme and Performance, 1960 - 1980. Cambridge: Cambridge University Press, 1985.

Cross, M., and R. G. Jobling. 'The English new universities - a preliminary enquiry.'

Universities Quarterly 23 (1969): 172-182.

Dyhouse, C., Students: A Gendered History. London: Routledge, 2006.

Edgerton, D., Warfare State. Britain, 1920-1970. Cambridge: Cambridge University Press, 2006.

Edgerton, D., Britain's War Machine. Weapons, Resources and Experts in the Second World War. London: Allen Lane, 2011.

Gallie, W., A New University: A. D. Lindsay and the Keele Experiment. London: Chatto \& Windus, 1960.

Halsey, A. H. 'British Universities and intellectual life.' Universities Quarterly 12 (1958): $141-152$

Jones, D. R., The Origins of Civic Universities. Manchester, Leeds and Liverpool. London: Routledge, 1988.

King, D., and V. Nash, 'Continuity of Ideas and the Politics of Higher Education Expansion in Britain from Robbins to Dearing.' Twentieth Century British History 12 (2001): 185-207 Kolbert, J. M., Keele, The First Fifty Years. Keele: Melandrium Books, 2000. McClintock, M. E., University of Lancaster: Quest for Innovation. A History of the First Ten Years, 1964-1974. Lancaster: University of Lancaster, 1974. 
McCrone, G., Regional Policy in Britain. London: Allen and Unwin, 1969.

Muthesius, S., The Post-war University. Utopianist Campus and College. New Haven: Yale University Press, 2006.

Ortolano, G., The Two Cultures Controversy. Science, Literature and Cultural Politics in Post-war Britain. Cambridge: Cambridge University Press, 2009.

Perkin, H. J., New Universities in the United Kingdom. Case Studies on Innovation in Higher Education. OECD, 1969.

Salter, B. and T. Tapper, The State and Higher Education. Ilford: Woburn Press, 1994.

Sanderson, M., The Universities and British Industry 1850 - 1970. London: Routledge and Kegan Paul, 1972.

Shattock, M. L., Making Policy in British Higher Education, 1948 - 2011. Maidenhead:

Open University Press, 2012.

Shattock, M. L., The UGC and the Management of British Universities. Buckingham: Open University Press, 1994.

Shinn, C. H, Paying the Piper. The Development of the University Grants Committee, 191946. London: Falmer Press, 1986.

Silver, H., Higher Education and Opinion Making in Twentieth-Century England. London: Woburn Press, 2003.

Smith, B., 'The impact of the University on the local community' in The Sussex Opportunity. A New University and the Future, edited by R. Blin-Stayle and G. Ivey, 50-65. Brighton: Harvester Press, 1986.

Stewart, W. A. C., Higher Education in Post-war Britain. London: Macmillan, 1989. Stone, W. G., 'Steps leading to the foundation of the university' in The Idea of a New University. An Experiment in Sussex edited by D. Daiches, 168 - 192. London: Andre Deutsch, 1964.

Tight. M, The Development of Higher Education in the United Kingdom since 1945. Maidenhead: Open University Press, 2009.

Trow, M., 'The idea of a new university.' Universities Quarterly 19 (1968): 162-172. Vernon, K., 'Civic universities and community engagement in inter-war England' in Beyond the Lecture Hall. Universities and community engagement from the middle ages to the present day. Edited by P. Cunningham, S. Oosthuizen and R. Taylor, 31-48. Cambridge: University of Cambridge, 2009. 
Vernon, K., 'A healthy society for future intellectuals: Developing student life at civic universities' in Regenerating England. Science, Medicine and Culture in Inter-war Britain. Edited by C. Lawrence and A-K Mayer, 179-202. Amsterdam: Rodopi, 2000.

Vernon, K., Universities and the State in England, 1850 - 1939. London: Routledgefalmer, 2004.

Whyte, W., Redbrick. A Social and Architectural History of Britain's Civic Universities. Oxford: Oxford University Press, 2015. 